\title{
Heavy Metals Concentrations in the Shell and Tissue of Periwinkle (Tympanotonus fuscatus) and Giant Land Snail (Achatina fulica) in Soku Community of Niger Delta, Nigeria.
}

\author{
Nwoko C.I.A. ${ }^{*}$, Ukiwe L.N. ${ }^{2}$, Oshoakpeme G.S. ${ }^{3}$, \\ ${ }^{1,2,3}$ Department of Chemistry, Federal University of Technology, Owerri, Nigeria \\ Corresponding author: nwokochristopher@yahoo.com
}

\begin{abstract}
The pollution of aquatic ecosystem by heavy metals has assumed serious proportions due to their toxicity and accumulative behaviour. River dams are especially at risk of contamination by different contaminants from anthropogenic sources including heavy metals since change of sediment regime often occur. The accumulation of five heavy metals; chromium (Cr), Cadmium (Cd), Lead (Pb), Copper (Cu) and Arsenic (As) in periwinkle, (Tympanotonus fuscatus, var, radula) and giant land snail (Achatina fulica) shell and soft tissue collected from Soku Community, Akuku-toru Local Government Area of Rivers State, Nigeria was studied. The periwinkle and giant land snail were processed and analyzed for heavy metals presence. Results obtained showed that the periwinkles accumulated more of the above mentioned heavy metals than the snail. Copper and arsenic were the highest concentrated heavy metals in the periwinkle shell soft tissue. The concentration of copper and arsenic in periwinkles soft tissue was found to be $1,612 \mathrm{mg} / \mathrm{kg}$ and $2.40 \mathrm{mg} / \mathrm{kg}$, respectively. In the giant land snail the soft tissue concentrated more of copper $(277 \mathrm{mg} / \mathrm{kg})$. These values exceeded set standards for guidelines on toxicity.
\end{abstract}

\section{Indexing terms/Keywords}

Accumulation; community; digestion; environment; fluorescence; pollution; seafood.

\section{Academic Discipline And Sub-Disciplines}

Environmental chemistry

\section{SUBJECT CLASSIFICATION}

Chemistry

\section{TYPE (METHOD/APPROACH)}

\section{Experimental}

\section{Council for Innovative Research}

Peer Review Research Publishing System

Journal: Journal of Advances in Chemistry

Vol. 10, No. 3

editorjaconline@gmail.com 


\subsection{INTRODUCTION}

Heavy metals (HMs) are intrinsic, natural constituents of our environment. They are generally present in small amounts in aquatic environments. Apart from natural sources, several anthropogenic activities also contribute to metal concentrations in the environment. In recent times, industrial activities have raised natural concentrations causing serious environmental problems. Biotic organisms are generally exposed to very high concentrations of these pollutants. Human may be contaminated by organic and inorganic pollutants associated with aquatic systems by consumption of contaminated fish and other aquatic foods from this environment. This fact is due to the capacity of some aquatic organisms to concentrate HMs up to 105 times the concentration present in the water.

It is difficult to remove HMs completely from the environment once they enter into it. With the increased use of a wide variety of metals and petrochemicals in industries coupled with African lifestyle of dumping wastes around indiscriminately, there is now a greater awareness of toxic metal pollution of the environment. Many of these metals tend to remain in the ecosystem and eventually move from one system to the other within the food chain. In addition, there has been proliferation of urban settlements and slum in the city of Port Harcourt and community around Rivers State, Nigeria, resulting in the generation of domestic effluents which combine with industrial effluents and eventually find their way into large body of water and serve as ultimate sink for HMs. This will cause physical and chemical changes to the quality of the receiving waters. These changes may include increased dissolved nutrients which may result in eutrophication, changes in stream temperature and bottom characteristics which lead to habitat destruction and alteration of species diversity and the addition of toxic substances which can have either acute or chronic effects on aquatic organisms. There is considerable concern about the human health aspects of metal cycling in polluted coastal and inland waters that are in proximity to large population centers. Several factors such as size, nature of the environment, seasonal variation and variability in species have been identified as important independent variables influencing metal levels in marine organisms [1]. The variation in metal level within biota is part of an indicative of the degree to which particular specie pick up particulate matter from the surrounding water and sediments while feeding. In natural aquatic ecosystems, metals occur normally in nanogram and microgram levels. However, some of these metals occurring at low concentrations in surface water are found in high concentrations in the corresponding sediments.

Bayan et al. [2] studied the levels of several HMs and persistent organic pollutants in edible portions of several seafood types and observed that the mean HMs concentrations among the seafood types ranged from below detection limits to $14.2 \mu \mathrm{g} / \mathrm{g}$ wet weight (ww) for arsenic (As), $0.50 \mu \mathrm{g} / \mathrm{g}(\mathrm{ww})$ for mercury (Hg), and $1.21 \mu \mathrm{g} / \mathrm{g}$ (ww) for lead (Pb), respectively. In a recent study, Järup [3] noted that hazards of HMs contamination in humans can occur when the general population is primarily exposed to $\mathrm{HMs}$ such as $\mathrm{Hg}$ through high fish consumption. The study further revealed that humans are exposed to $\mathrm{Pb}$ from air and food in roughly equal proportions. Children are exceptionally susceptible to $\mathrm{Pb}$ exposure, the study reported, due to high gastrointestinal uptake and permeable blood-brain barrier. Another study by Wang et al. [4] observed the following evaluations in marine organisms investigated; seaweed $(0.4513 \mathrm{mg} / \mathrm{kg})$, marine molluscs (0.1155 $\mathrm{mg} / \mathrm{kg})$, marine crustaceans $(0.0486 \mathrm{mg} / \mathrm{kg})$, and sea-fish $(0.0419 \mathrm{mg} / \mathrm{kg})$, respectively. The study further concluded that the situation of HMs presence in different kinds of marine organisms vary with algae and sea fish being the most polluted, while sea water crustaceans the least contaminated. Evaluation by pollution index showed that $\mathrm{Pb}$ was the least present in the organisms, while cadmium (Cd) was excessively present in the sea water and algae.

Sestons are the minute particulate materials in water bodies such as lakes and seas, and include both living organisms (plankton and nekton), and non living matter (plant debris or suspended soil particles). Seston sediments were collected and analyzed seasonally for the presence of $\mathrm{Cd}, \mathrm{Pb}$, and copper $(\mathrm{Cu})$. It was revealed that levels of $\mathrm{Cd}, \mathrm{Pb}$, and $\mathrm{Cu}$ were considerably high in seston sediments in winter periods and in areas of high industrial activities. These reported levels of the three HMs were also high in samples of fish flesh analyzed. The study also demonstrated that the data obtained represent the current HMs profile in the sampled area and could be used as a background bench mark for which further improvements in water quality may be established [5]. In a related report, Astudillol et al. [6] investigated HMs presence in sediments in mussels and oysters. Their study revealed that the levels of $\mathrm{Hg}$ exceeded set standard guidelines, while $\mathrm{Cd}, \mathrm{Cu}$, nickel (Ni), Pb and Zinc ( $\mathrm{Zn})$, also exceeded these guidelines at several sites. Heavy metal (HM) presence in oysters and mussels varied widely with locations. The study concluded that while mussels may be a better biological indicator of HM pollution in sediments than oysters, the latter may serve as a source of further contamination by $\mathrm{Cu}$ and $\mathrm{Zn}$. Concentrations of seven HMs have also been separately determined in green mussels (Perna viridis) collected between April and June from eight locations along the coastal area of the Gulf of Thailand. The average concentrations of $\mathrm{HMs}$ detected in the mussels samples on the basis of dry weight were $1.20 \mathrm{mg} / \mathrm{kg} \mathrm{Cd}, 0.78 \mathrm{mg} / \mathrm{kg} \mathrm{chromium} \mathrm{(Cr),} 9.85$ $\mathrm{mg} / \mathrm{kg} \mathrm{Cu}, 1.09 \mathrm{mg} / \mathrm{kg} \mathrm{Pb}, 2.78 \mathrm{mg} / \mathrm{kg}$ manganese (Mn), $1.54 \mathrm{mg} / \mathrm{kg} \mathrm{Ni}$, and $94.48 \mathrm{mg} / \mathrm{kg} \mathrm{Zn}$, respectively. The levels of $\mathrm{Cd}, \mathrm{Cr}, \mathrm{Ni}$, and $\mathrm{Pb}$ respectively found in the mussels from four locations in the Upper Gulf region were significantly higher than those detected in mussels from the other four locations in the Lower Gulf region. While the levels of $\mathrm{Cu}, \mathrm{Mn}$, and $\mathrm{Zn}$ did not differ significantly between the Upper and Lower Gulf regions, comparison with earlier studies revealed that the concentrations of some HMs in the mussels collected from the Lower and Upper Gulf regions were within acceptable limits for human consumption [7].

\subsection{Materials and Method}

\subsection{Study area}

This research work area was Soku, Community of Akuku-toru Local Government Area of Rivers State, Nigeria. It has an area of $1,443 \mathrm{~km} 2$ and a population of 156,006 at the 2006 census. Soku community is one of several communities that makes up the Abonnema kingdom. Soku's geographical coordinates are $4^{\circ} 4110^{\prime \prime}$ North, $6^{\circ} 4110^{\prime \prime}$ East, the river is 
located at an elevation of 372 meters above the sea level and has coordinates $8^{0} 9^{1} 0^{\prime \prime} \mathrm{N}$ and $11^{\circ} 24^{\prime} 0^{\prime \prime} \mathrm{E}$ or 8.15 and 11.4 (in decimal degrees). Soku community is on Latitude $4^{\circ} 38^{\prime} 58^{\prime \prime} \mathrm{N}$ and longitude $6^{\circ} 34^{\prime} 14^{\prime \prime} \mathrm{E}$.

\subsection{Sampling and sample preparation}

The sampling was performed in the River Soku of Soku Community of Akuku-toru Local Government Area of Rivers State, Nigeria. The test animals were the periwinkle (Tympanotonous fuscatus) and the giant land snail (Achatina Fulica) of similar sizes (shell length of 28 to $31 \mathrm{~mm}$ ) were collected by hand picking into a plastic bucket during low tide in the Soku River. The periwinkles were collected from the same site, in order to reduce variability in biotype. The animals were transported to the laboratory and kept in holding glass tanks $(30 \times 30 \times 30 \mathrm{~cm})$, which contained aerated water from the sampling site. In the laboratory $30 \mathrm{~g}$ of the muscle tissue was removed (both of periwinkles and snails) with the help of a stainless steel surgery knife and the samples freeze-dried and ground into a homogenous mixture using a porcelain mortar and pestle. The shells of the test animals were crushed with the help of a crusher into homogenous mixture. About $1 \mathrm{~g}$ of sample in-triplicate of homogenous mixture of the tissues of both animals was submitted to strong acid digestion $\left(\mathrm{HCl}+\mathrm{HNO}_{3}\right.$ conc. 3:1) in a glass tube block digester. After complete dissolution, the acid was evaporated to almost dryness and dissolved in $0.5 \mathrm{M} \mathrm{HCl}$. Heavy metal determination ( $\mathrm{As}, \mathrm{Cu}, \mathrm{Cd}, \mathrm{Cr}$ and $\mathrm{Pb}$ ) was performed with $\mathrm{X}$-Ray fluorescence (model ZSX Primus II, UK) and the results expressed in $\mathrm{mg} / \mathrm{kg}$ of dry weight (w/w).

The reagents used for this study were of analytical grade. All glassware were soaked in $10 \%(\mathrm{v} / \mathrm{v}) \mathrm{HNO}_{3}$ for 2 hours and later rinsed with distilled de-ionized water prior to use for metal analysis. Distilled water was used for the preparation of all solutions.

A mixture of $\mathrm{HCl}$ and $\mathrm{HNO}_{3}$ acid in the ratio $3: 1$ (aqua regia) was used. About $1.5 \mathrm{~g}$ of each blended sample of periwinkle and snail was weighed into a $200 \mathrm{ml}$ beaker, and about $10 \mathrm{ml}$ of aqua regia was added and the beaker covered with a watch glass. This was placed on a thermostatically controlled hot plate maintained at temperature of $110^{\circ} \mathrm{C}$ for $1 \mathrm{~h}$ with intermittent addition of deionised water to avoid drying up of the mixture. The beaker and the watch glass were cooled and its content transferred into analytical bottles and made up to $25 \mathrm{ml}$ with distilled water. The digested samples were then analyzed for HM concentration. Three treatments were performed and the mean concentration $(\mathrm{mg} / \mathrm{kg})$ of the HMs obtained.

\subsection{Results and Discussion}

Table 1: Concentration of heavy metals in shell and soft tissue of periwinkle and snail

\begin{tabular}{lcccc}
\hline \multicolumn{2}{c}{ Organisms } & \multicolumn{2}{c}{ Periwinkle } & \multicolumn{2}{c}{ Snail } \\
$\begin{array}{l}\text { Parameters } \\
\text { mean }(\mathbf{m g} / \mathbf{k g})\end{array}$ & Shell mean $(\mathbf{m g} / \mathbf{k g})$ & Soft tissue mean $(\mathbf{m g} / \mathbf{k g})$ & Shell mean $(\mathbf{m g} / \mathbf{k g})$ & Soft tissue \\
\hline $\mathrm{Pb}$ & $<1.00$ & $<1.00$ & $<1.00$ & $<1.00$ \\
$\mathrm{Cd}$ & $<0.10$ & $<0.10$ & $<2.00$ & $<0.10$ \\
$\mathrm{Cr}$ & $<1.00$ & $<1.00$ & $<1.00$ & $<1.00$ \\
$\mathrm{Cu}$ & 56.6 & 1,612 & 10.4 & 277 \\
$\mathrm{As}$ & 1.80 & 2.40 & $<0.50$ & $<0.50$
\end{tabular}

Table 1. show the concentration of $\mathrm{Pb}, \mathrm{Cd}, \mathrm{Cr}, \mathrm{Cu}$, and $\mathrm{As}$ in samples of periwinkle and snail shells and tissue. In the periwinkle shell/tissue, $\mathrm{Pb}$ obtained was $<1.00 /<1.00 \mathrm{mg} / \mathrm{kg}$ for both shell and tissue. Other results obtained for the shell/tissue of the other metals include; $\mathrm{Cd}(<0.10 /<0.10 \mathrm{mg} / \mathrm{kg}), \mathrm{Cr}(<1.00 / 1.00 \mathrm{mg} / \mathrm{kg}), \mathrm{Cu}(56.6 / 1,612 \mathrm{mg} / \mathrm{kg})$, and As $(1.80 / 2.40 \mathrm{mg} / \mathrm{kg})$, while in the snail shell/tissue the following results were obtained; $\mathrm{Pb}(<1.00 /<1.00 \mathrm{mg} / \mathrm{kg}), \mathrm{Cd}$ $(2.00 /<0.10 \mathrm{mg} / \mathrm{kg}), \mathrm{Cr}(<1.00 / 1.00 \mathrm{mg} / \mathrm{kg}), \mathrm{Cu}(10.4 / 277 \mathrm{mg} / \mathrm{kg})$, and As $(<0.50 /<0.50 \mathrm{mg} / \mathrm{kg})$. It was observed that the periwinkle soft tissue accumulated more $\mathrm{Cu}(1,612 \mathrm{mg} / \mathrm{kg})$ than the snail soft tissue. Also, it was noted that $\mathrm{Cu}$ was the highest metal accumulated by the shell of both organisms (periwinkle; Cu $(56.6 \mathrm{mg} / \mathrm{kg}$ ) and snail, Cu (10.4 mg/kg). The high levels of $\mathrm{Cu}$ in the shell and soft tissue of these organisms might be attributed to anthropogenic activities arising from solid and liquid wastes discharge by cottage industries located around the sample situation. While other metals investigated were within set standard guidelines, it should be stated that consuming the periwinkle and snail tissue could lead to Cu pollution in humans.

Olowoye [8] had earlier studied the concentrations of $\mathrm{HMs} \mathrm{Pb}, \mathrm{Ni}, \mathrm{Fe}, \mathrm{Cu}, \mathrm{Zn}, \mathrm{Cd}, \mathrm{Mn}$, and $\mathrm{Cr}$ in periwinkle and found that the concentrations of $\mathrm{Pb}$ ranged between $0.68-10.34 \mathrm{mg} / \mathrm{kg}, \mathrm{Cd}(0.002-0.54 \mathrm{mg} / \mathrm{kg}), \mathrm{Cu}(0.002-60 \mathrm{mg} / \mathrm{kg})$, and $\mathrm{Cr}(205.09$ $1,435 \mathrm{mg} / \mathrm{kg}$ ), respectively. These results were far higher than those obtained in the present study especially for $\mathrm{Pb}$ and $\mathrm{Cr}$. In further studies [9], it was revealed that the presence of $\mathrm{Zn}$ in mangrove periwinkles was able to reduce the toxic effect of $\mathrm{Cu}$ and $\mathrm{Cd}$, and that there was a possibility of utilizing the observed antagonistic interactions between $\mathrm{Zn}$ and $\mathrm{Cd}$ in the management of $\mathrm{Cd}$-contaminated water bodies. The present study did not notice any interaction between the HMs investigated. While noting that there is a possibility of antagonistic behaviour between metals, the present research would advice for more investigations in this aspect before a concrete conclusion is established.

Other studies on HMs presence in mangrove periwinkle include that of Davies et al. [10], who studied bioaccumulation of $\mathrm{HM}$ in water, and periwinkle, Dewolf et al. [11], who investigated the accumulation of HM in periwinkle 
along a pollution gradient in the Scheidt estuary and Chindah et al. [12], who also examined HM concentrations in sediment and periwinkle in different ecological zones of Bonny River system, Niger Delta, Nigeria. In all these studies as well as that of [13], [14], and [15], the level of HMs were within set standard limit guidelines, agreeing with the present investigation that mangrove periwinkles from the Niger Delta, Nigeria do not accumulate most HMs to such levels as being detrimental for consumption and affect humans health adversely.

\section{CONCLUSION}

The present study investigated HMs in shells and in soft tissues of mangrove periwinkles (Tympanotonus fuscatus) and giant land snail (Achatina fulica) with the highest HMs presence noted in the soft tissue for Cu on both organisms (1,612 $\mathrm{mg} / \mathrm{kg}$ for periwinkle and $277 \mathrm{mg} / \mathrm{kgfor}$ snail). Cu was also present in significant quantity in the shells of both organisms (56.6 mg/kg for periwinkle and $10.4 \mathrm{mg} / \mathrm{kg}$ for snail). However, $\mathrm{Pb}$ and Cd were within acceptable limits of standard guidelines. These results could serve as an indicator to monitor water quality levels of Cu pollution.

\section{REFERENCES}

1. Leung, K.M.Y., Furness, R.W. Effects of animal bioaccumulation of heavy metals in water size on concentrations of metallothionein, sediments and periwinkle from Elechi Crek in Niger Delta, Nigeria. African Journal of Biotechnology, (1999). 5:968-973.

2. Bayen, S., Koroleva, E., Lee, H.K., Obbard, J.P. Persistent organic pollutants and heavy metals in typical sea foods consumed in Singapore. Journal of Toxicology and Environmental Health A, (2005). 68:151-106.

3. Järup, L. Hazards of heavy metal contamination. British Medical Bulletin, (2003). 68:167-182.

4. Wang, J.Y., Wang, Y.C., Lou, J.H. Analysis on heavy metal pollution in major seafoods from Zhoushan fishery, China. Zhoughua Liu Xing Bing Xue Za Zhi, (2012). 33:1001-1004.

5. Edwards, J.W., Edwane, K.S., Boxall, V.A., Hamann, M., Metal levels in seston and marine fish flesh near industrial and metropolitan centres in South Australia. Marine Pollution Bulletin, (2001). 42:389-396.

6. Astudillol, L.R., Yen, I.C., Bekele, I. Heavy metals in sediments, mussels and oysters from Trinidad and Venezuela. Revista de Biologia Tropical, (2005). 53:41-53.

7. Ruangwises, N., Ruangwises, S. Heavy metals in green mussels (Perna viridis) from the Gulf of Thailand. Journal of Food Production, (1993). 6:94-97.

8. Olowoyo, D.N. Heavy metal concentrations in periwinkle (Littorina littorea and tilapia (Tilapia zilli) from the coastal water of Warri, Nigeria. American Journal of Food and Nutrition, (2011). 1:102-108.

9. Otitoloju, A.A. Evaluation of the joint-action toxicity of binary mixtures of heavy metals against the mangrove periwinkle (Tympanotonus fuscatus var radula). Ecotoxicology and Ehvironmental Safety, (2002). 53: 404-415.

10 Davies, O.A., Allison, M.E., Uju, H.S. Bioaccumulation of heavy metals in water, sediment and periwinkle (Tympanotonus fuscatus var radula from the Elechi Creek, Niger Delta. African Journal of Biotechnology, (2006). 5: 968-973.

11 De Wolf, H, Backeljau, T., Blust, R. Heavy metal accumulation in the periwinkle (Littorina littorea), a long a pollution gradient in the scheidt estuary. (2000). 262: 111-121.

12 Chindah, A.C., Braide, S.A., Amakiri, J., Chikwendu, S.O.N. Heavy metal concentrations in sediment and periwinkle (Tympanotonus fuscatus) in the different ecological zones of Bonny River system, Niger Delta, Nigeria. The Open Environmental Pollution \& Toxicology Journal, (2009). 1: 93-106.

13 Ayenimo, J.G., Adeeyinwo, C.E., Amoo, I.A, Odukudu, F.B. A preliminary investigation of heavy metals in periwinkles from Warri River, Nigeria. Journal of Applied Sciences, (2005). 5: 813-815.

14 Nwabueze, A.A., Nwabueze, E.O., Okonkwo C.N. Petroleum hydrocarbons and heavy metal concentrations in tissues of periwinkles (Tympanotonus fuscatus) from Warri River in Nigeria. International Journal of Water and Soil Resources Research, (2010). 1: 41-45.

15 Ikejimba, C.C., Sakpa S. Comparative study of some heavy metals concentrations in water and Tympanotonus fuscatus Var radula samples of Egbokodo River, Warri, Nigeria. International Journal of Modern Biological Research, (2013). 2:7-15. 